\title{
To Explore the Character Design Education Reform in Higher Vocational Colleges
}

\author{
Xiaoyan ZHANG \\ Shanghai Second Polytechnic University, Shanghai, China
}

\begin{abstract}
Character design vocational education institutions are not mature yet. Existence positioning is unclear, curriculum loose, educational model rigidities. In education reform, the design should be between globalization and local educational cultural to find points of integration, in order to cultivate the students' professional point to explore the characteristics of vocational education in line with the new model, closely integrated with social practice.
\end{abstract}

KEYWORD: Vocational education; Character design; Educational reform; Exploration

\section{INTRODUCTION}

Since 2000, China's colleges and universities have set up character design professional, society has trained a large number of figures related practitioners. Compared colleges, vocational colleges character design more targeted teaching positions, not only requires students to master job skills, but also with a certain design capability and ability to execute projects. So, how to get between the professional courses, there is a more rational allocation between theory and practice, how to develop students' professional qualities Program within three years, how to create an effective mode of interaction between school education and social practice, how to create a match with the reform and development of professional teachers, are the main problems facing education reform.

\section{CHARACTER EDUCATION REFORM: "GLOBAL AND LOCAL" PHILOSOPHY OF EDUCATION OF EXPLORATION AND PRACTICE}

With the development of network technology, fashion information economy and globalization provide a great convenience for the character design education, but also on the training objectives of the school presented a challenge. Strengthen college characteristics, establish education brand, to become the character design education to deal with competition, seize opportunities, strategic decisions. Therefore, we must find a point of integration with the global education philosophy of education and culture of the local community, to make professional education on the path of sustainable development.

\subsection{Currently our character design education vocational colleges Problems}

Currently vocational character design education problems are mainly embodied in the following three areas:

First, the positioning of vocational education character modeling. This issue involves a very wide area, most prominently reflected in the use of materials on. Vocational education is mainly taskoriented students through the planning and execution of a specific task or project work familiar demand jobs will learn to apply their knowledge of technology. In designing the characters for the current vocational teaching, teachers' choice of teaching content migration between undergraduate teaching and social training materials, character design professional has yet to complete one of the ideal materials suitable for vocational students. This is not only inconvenient to teaching and professional vocational colleges make the concept of "character design" has become blurred, showing the ambiguous status of social training and teaching undergraduate theory a cross between. Therefore, the construction of a systematic task-oriented, character modeling professional for teaching meaningful sustainable development is imminent, on this basis, vocational education character modeling can only have a clear positioning, real and concrete combine social positions.

Second, curriculum issues. character modeling are many professional vocational colleges seem to 
have a more complete set of professional subjects, but in terms of the integrity and effectiveness of the education system, there are still many shortcomings. Bridging between the various programs is not strong; the relationship will not allow students to learn the process of linking various courses. In addition, integration between design theory and practical operation of the task does not close, practical course content practicality is not strong; the knowledge cannot be used, so many students to complete their studies after a lack of confidence in the face of actual work, and feel helpless.

Third, the educational model problem. In vocational education mode, the practical part is often more than $50 \%$. While many colleges also follow the character design education theory and practice of both this mode of education, but will always be regarded as two separate modules to each other, and the lack of valuable social practice, the advantages of higher vocational education cannot be play.

\subsection{Enlightenment of Foreign Art and Design education model}

Foreign art design education model and vocational education in China is similar to laboratory-based, thematic design projects as the main refining the theory in practice, the formation of a separate education system. American Cranbrook Academy of Art: school-enterprise cooperation, production research integration. After the Nazis closed the Bauhaus School of design talent to move to the United States, the United States became the center of design education. Cranbrook Academy of Design developed the Bauhaus modern design ideas, home design and furniture company specialized long-term cooperation to create a "school-enterprise cooperation, combining production" model. It selection from students outstanding design talents to open "studio" as the main teaching mode, the formation of industry, academia, research integration model, founded the American elite design education brand.

University of Wolverhampton, UK: combining traditional and modern factory-style education model. University of Wolverhampton in the English arts and crafts tradition and modern design combined, mainly reflected in the glass and ceramic design education mode. It has a range of technology processing lines and plants, work needs kiln, polishing, glazing, casting and other equipment readily available, as a complete plant. British glass design products are the world's largest consumer of luxury, nature and the University of Wolverhampton training a large number of professionals are closely related.

University of Art and Design in Helsinki, Finland: Professor studio + factory-style teaching. College equipment, just as a separate facility, each student has a separate table in the studio by a professor of theory and practice guidance, and then put the factory floor exercise professional competence. Manufacturing production and social work from design to post almost unanimously, cultivate top talents to work and study.

As can be seen from the educational model class foreign School of Design, between theory and practice, the boundaries between school education and practical work is very vague, theoretical constantly be updated on the basis of technological innovation.

Vocational education through the exploration and hone technique to accumulate experiences and achievements naturally formed precise positioning and professional education brand with professional features, so that design education has a unique value.

With our emphasis on vocational education, the state training equipment, laboratory construction put a lot of money, a lot of vocational colleges have the best equipment repairing strength, and character design education is also one of the beneficiaries. However, how to define the character design of the meaning and purpose of education, have full use of favorable conditions to develop students' professional equipment quality, which is the fundamental problem facing the education reform. Character design of vocational education should not blindly copy foreign models, but should local educational resources, education, culture, industry needs, formed to train qualified professional personnel to point to the practice of modern education model.

\section{CHARACTER DESIGN POINT OF EDUCATION REFORM: THE OVERALL QUALITY OF STUDENTS}

\subsection{Scientific work: to develop work habits}

According to the specific circumstances of the task of research, setting up a series of workflows, designing the characters will become an important education reform work. In practical work, or project implementation, will have to follow certain work processes, work well underway. Theory and Practice of relatively independent undergraduate education model obviously does not apply to the task-oriented vocational education basic features. Standardized work processes from design to allow students a clear relationship between the various stages of production, and thus fully understand the objectives and requirements of each stage of the work required to effectively perform the tasks at work. In times of difficulties, but also can find links difficulty, to find an appropriate solution. Establish a scientific work can not only help students adapt to the working methods of the future, but also to cultivate their methodical work habits. 


\subsection{Symbols of the collection, interpretation and restructuring: Identify problems and develop problem-solving skills}

Since the early 20's semiotic theory proposed to explore the concerns and combinations of symbols for the design and research fields, character design is no exception. Character design in vocational colleges of education reform, it should abandon the traditional form and shape in the form of inspired mode, instead focus on training students for visual acuity symbols so that they pay attention to every little thing in life, with a design vision to observe and think. For people who are engaged in the design, discovery problem is more important than solving problems, contacts and features is only good at finding things in between, to extract its corresponding visual symbols, and be collecting, classification, interpretation and restructuring, to the figures generate creative design, or can quickly find a way to solve the problem. Train students in the design process concept and symbol acumen, not only conducive to the development of their design capabilities, but also conducive to the growth of their hearts.

\subsection{Conceived and implemented the structure: fostering design capabilities, ability to operate}

Character design in education reform, teachers should weaken traditional teaching predominance, the ability to develop students' ability to plan and focus on problem solving. Vocational education and training character design is to understand the design methods, and can work independently in the actual work of technical operations personnel, so the students are very concerned about production capacity, which is the weak point of Undergraduate Education. Vocational institutions in the current image of the character design education, often the results of the project in the first place, teachers often act as dominant in the production, and even "arranged" role. However, students design capabilities, ability to think independently but all need to be honed and hands-on production. Thus, the structural analysis of education reform as a teaching before making key content, students can design ability and physical structure reflects the ability to develop and increase production capacity and lay a solid foundation.

\subsection{Project Summary and expansion: ability to work independently and creativity training}

Character design education reform to quality training to point at the end of each project, a summary of the proposed project and the expansion of the initial results of the program will be an important part of the reform of the education system.
Through a comprehensive summary of the process of the project, the results of the self-evaluation of the project, as well as generate envisaged the establishment and implementation of the next stage of the project according to the results of the project, enabling students to clearly understand all aspects of their interim status, develop their ability to work independently, sense of responsibility, as well as the ability to create realistic basis. This quality is the desire of the employer, also higher vocational institutions and personnel training objectives consistent.

\section{CHARACTER DESIGN EDUCATION REFORM MODELS: CLASSROOM / LABORATORY - STUDIO - SOCIAL PRACTICE}

The foreign advanced art and technology training model tells us, the College of Education at the forefront of the industry, but also should be closely integrated with the actual work, the ability of graduates should not have much of a difference between job demands. Although the idea of education reform to improve the quality of talent can play a big role, but in practice mode to run educational reform from the facilities and allow the construction of character design education model vocational colleges produce significant improvements, with more broad space for development. Character design education reform model roughly follows the classroom / laboratory studio - social practice mode, vocational education to meet the early, middle, and high levels of training required to make college education and social work practice skills combined with smooth tight make full use of educational resources, form a unique character vocational colleges design education.

\subsection{Classroom / Lab: basic theory and skills of learning}

In the early stages of learning, requiring students to master basic skills and design thinking lab is the main place them in practice-based teaching and training. Today, character design specialized laboratories in many vocational colleges multimedia devices installed, photography, video equipment, combining theory and practice of teaching provides a great convenience. In the first year after enrollment, students will complete beauty makeup base, foundation draping, professional graphics and three-dimensional forms the basis for the foundation and other basic theory and skills courses. Character design vocational education training class and set a lot more than three weeks of training each semester, giving students ample opportunity to get a comprehensive theoretical and practical training of 
high-intensity, after the project for promoting the teaching of great help . Laboratory is not only a lowgrade students skills training establishments, the implementation of the project base also produced high-grade college students and school-enterprise cooperation projects. Therefore, the required character design training room clear classification, facilities, rigorous system to actually build workflow-oriented, each laboratory has its own role and characteristics, there are enough resources for students to participate in professional practice training. Laboratory internal settings should work place as a unit, each student in a different time period has its own fixed bench, making products and tools can be reasonably accommodated, at any time when needed laboratory resources can be deployed operation. This is not only convenient for laboratory management, but also allows students to develop good work habits, develop an interest in participating in practical training, the formation of a strong hands-on learning environment.

\subsection{Studio: Full implementation of the project and demonstrate}

From the beginning of the second year of enrollment, students began to enter the professional teachers under the auspices of the design studio to begin production of specific projects, the theory and skills learned in the first grade into practical applications. The main task as a design studio, production is largely dependent on the laboratory. Studio is school of education and social Communication is a window, according to the teaching of teachers in addition to plans to set project tasks should be more cross-cutting projects in cooperation with enterprises to introduce studio teaching, allowing students to participate in the planning and implementation together at the same time familiar to apply their knowledge of the actual work, and to show their ability and potential to the community through interaction with the enterprise. Located in the heart of Tokyo, Japan, Hollywood character design on the ground floor of the school opened a clothing style studio, to the display of the students' development efforts. Students created costumes can be sold, but still the main purpose of teaching research, not for profit, this is available for our vocational colleges' reference.

The establishment and effective operation of the studio can promote the development of schoolenterprise cooperation, avoid inflexible and backward professional education is conducive to raising the level of education and educational brand building. Character design needs education and social services in vocational colleges have a direct relationship, open studio to give professional development has brought more opportunities.

\subsection{Society: become qualified designers}

In the final year, students enter the next phase of the internship. After Enterprise systematic training, the students will become qualified designers. Currently, many vocational colleges in order to strengthen vocational education and related social needs, to encourage teachers to corporate exercise. However, due to the implementation of this system in contact with a professional education is not strong, acceptance criteria and requirements are unclear and gradually a mere formality, the original intention increasing the gap between establishment. Character design in vocational colleges of education reform, we should strengthen the relationship between teaching and practice, so that teachers accompany students to participate in internships together, in cooperation with companies, completed a smooth docking studio training and social practice. This work included the teaching plan an important part of the content and workload assessment, schoolenterprise cooperation was truly implemented.

\section{CHARACTER DESIGN EDUCATION REFORM REQUIREMENTS FOR TEACHERS}

In designing the characters on the occasion of the education reform, teachers should also improve their quality. Currently, the character design professional vocational colleges established late start, mainly by teachers from colleges of clothing, stage design professional talent and industry senior technicians, whose professional background and the experience and vocational education model institutions "taskoriented", "both theory and practice" model of education there are many needs grinding. Therefore, to improve faculty from several major considerations: First, to re-recognize the nature of the task and the character design vocational colleges of education to jobs and social needs adjustment as the main reference for the teaching program, the rational allocation of professional courses, increase the proportion of practical courses, focus on personnel training and technical capabilities of both teaching ability, and systems theory and undergraduate distance education mode. Second, to encourage teachers are not limited to their own field, the systematic study of designing the characters other related professional knowledge, multi-skill and improve the overall level of business faculty, strengthen cohesion within the team teaching. Third, to promote contact between teachers and industry, as much as possible the introduction of valuable business cooperation projects, promote the construction of the studio building and practical education, to achieve "production, learning and research" one-stop career education model, the 
vocational figures design education reform implemented.

Character design vocational colleges of education reform to the times, technology and vocational education closely linked to both theories, colleges and corporate joint educational philosophy, in order to establish a unique brand of education, to develop a broader future.

\section{ACKNOWLEDGEMENT}

This research was financially supported by Shanghai Second Polytechnic University (XXKPY1316)

\section{REFERENCES}

[1] DAI Duan, November 2005, "Design Education Management global context to explore innovative practices", " ornament"

[2] ZHOU Yanling \& ZHANG Yujin, August 2005, "Comparison and analysis of Chinese and foreign higher education of art design", " Journal of Hanshan Normal University"

[3] YANG Mo, January 2005, "symbol - character design visual mother tongue" "Journal of Yunnan Arts University"

[4] Lu Jianhua, November 2007, "on the basis of design education in the value of design consideration" "success (education)" 